\title{
ПРО РОЗРАХУНОК ТЕМПЕРАТУРИ САМОЗІГРІВАННЯ СИРОВИНИ В ЦИЛІНДРИЧНИХ ЄМНОСТЯХ
}

\author{
Василь Ольшанський ${ }^{1}$, д. ф.-М. н., Сергій Харченко ${ }^{1}$, д. т. н., \\ Максим Сліпченко $^{1}$, к. т. н., Степан Ковалишин ${ }^{2}$, к. т. н., Михайло Мазурак ${ }^{3}$ \\ ${ }^{1}$ Державний біотехнологічний університет, \\ вул. Алчевських, 44, м. Харків, Україна, \\ e-mail: kharchenko_mtf@ukr.net \\ ${ }^{2}$ Львівський національний аграрний університет, \\ вул. Володимира Великого, 1, м. Дубляни, Львівський р-н, Львівська обл., Україна, \\ e-mail:stkovalyshyn@gmail.com \\ ${ }^{3}$ Львівська філія УкрНДІПВТ ім. Л. Погорілого, \\ вул. Л. Мартовича, 15, смт Магерів, Жовківський р-н, Львівська обл., Украӥна
}

https://doi.org/10.31734/agroengineering2021.25.021

\begin{abstract}
Ольшанський В., Харченко С., Сліпченко М., Ковалишин С., Мазурак М. Про розрахунок температури самозігрівання сировини в циліндричних ємностях

Розглянуто температурне поле органічної сировини в циліндричному силосі за наявності в ньому стрижньового осередку самозігрівання кругового поперечного перерізу. Аналітичний розв'язок нестаціонарної задачі теплопровідності виражено рядом Фур'є-Бесселя, при різних варіантах розподілу термоджерел в осередку самозігрівання. Показано, що рівномірний розподіл (однорідний осередок) дає найбільш швидкий приріст температури. Проаналізовано збіжність ряду, яким описано температурне поле. Встановлено, що збіжність поліпшується з плином часу, але вона дуже повільна на початку процесу самозігрівання. Запропоновано спосіб прискорення збіжності розв'язків задачі для окремих варіантів розподілу термоджерел. Побудовано графіки для ідентифікації радіуса осередку й подальшого визначення інтенсивності теплоджерел у ньому, при трьох варіантах ix розподілу. Ідентифікація грунтується на експериментальному вимірюванні приросту температур у центрі осередку за вибраний час. Це обмежує можливості методу, бо за великих розмірів осередку приріст температури в його центрі стає лінійним, як у необмеженому тілі з рівномірним розподілом термоджерел. Тому побудовані графіки втрачають сепарабельність великих розмірів осередку. Наведено приклади ідентифікації з використанням графіків. Показана можливість розрахункового прогнозу розвитку температури самозігрівання після проведення ідентифікації. Одержаний аналітичний розв'язок нестаціонарної задачі теплопровідності в поєднанні 3 експериментальним вимірюванням температури в центрі осередку самозігрівання дає змогу визначити параметри внугрішнього локалізованого термоджерела й провести прогноз розвитку температури самозігрівання.
\end{abstract}

Ключові слова: циліндрична ємність, стрижньовий осередок самозігрівання, температурне поле, ряд Фур'єБесселя, ідентифікація параметрів осередку, прогноз приросту температури в часі.

Olshanskyi V., Kharchenko S., Slipchenko M., Kovalyshyn S., Mazurak M. On calculation of the temperature of raw material self-heating in cylindrical tanks

The article considers the temperature field of organic raw materials in a cylindrical silo under presence of a rod center of self-heating of circular cross section. The analytical solution of the nonstationary thermal conductivity problem is expressed by the Fourier-Bessel series, with different variants of distribution of the thermal sources in the self-heating center. It is shown that a uniform distribution (homogeneous cell) gives the fastest increase in temperature. The convergence of the series describing the temperature field is analyzed. The convergence has been found to improve over time, but it is very slow at the beginning of the self-heating process. A method for accelerating the convergence of the solutions of the problem for individual variants of the thermal sources distribution is proposed. Graphs are constructed to identify radius of the cell and further determine the intensity of heat sources in it, with three options for their distribution. Identification is based on experimental measurement of the temperature increase in the center of the cell for the selected time. It limits the method possibilities, because at large cell sizes, the increase in temperature in its center becomes linear, as in an unlimited body with a uniform distribution of thermal sources. Therefore, the constructed graphs lose the separability of large cell sizes. Examples of identification using graphs are given. The research describes a possibility to make an estimated forecast of development of the self-heating temperature after conducted identification. The ontained analytical solution of nonstationary problems of heat conductivity in combination with the experimental measuring of temperature in the self-heating center provides for determination of the parameters of the internally located temperature self-projection.

Key words: cylindrical tanks, self-heating core, temperature field, Fourier-Bessel series, identification of cell parameters, forecast of temperature increase over time. 
Постановка проблеми та аналіз останніх досліджень і публікацій. Самозігрівання рослинної сировини в силосах (ємностях) належить до шкідливих явищ. Порушення температурного режиму зберігання сировини призводить до погіршення іiі якості, а іноді й повного псування. Відомі також випадки, коли самозігрівання сировини було причиною пожеж на елеваторах [4; $5 ; 8]$. У такому разі воно стає небезпечним. Тому вже тривалий час приділяється увага дослідженню температур у силосах у разі появи осередків самозігрівання $[6 ; 14-16]$. У математичних моделях температурних полів найпоширеніші три форми осередків: пластовий $[9 ; 11 ; 18]$, гніздовий $[10-13 ; 19]$ і стрижневий $[1 ; 2 ; 11]$. Тут, аналогічно $[1 ; 2]$, розглядаємо задачу нестаціонарної теплопровідності для силосу циліндричної форми при виникненні в ньому стрижневого осередку самозігрівання такого ж поперечного перерізу. Розглядаємо різні варіанти розподілу термоджерел в осередку. Ставиться також зворотна задача стосовно визначення потужності термоджерел за результатами вимірювання зміни температури в часі, a також подальшого прогнозування іiі розвитку в рамках розробленої моделі.

Постановка завдання. Наше завдання виведення математичних виразів для обчислення температури самозігрівання в неоднорідному стрижневому осередку кругового поперечного перерізу за різних варіантів розподілу термоджерел.

Виклад основного матеріалу. Основна частина роботи. Розглядаємо круговий циліндричний силос радіуса $R$, на вертикальній осі якого виник центральний стрижневий осередок радіуса $r_{0}$ (рис. 1). У рамках осесиметричної задачі щільність термоджерел по поперечному перерізу (за радикальною координатою $r$ ) описуємо виразом

$$
q(r)=\left\{\begin{array}{cc}
q_{0}\left(1-\frac{r^{2}}{r_{0}^{2}}\right)^{\mu} \text { при } \begin{array}{l}
r \leq r_{0} \\
0
\end{array} & r r_{0},
\end{array}\right.
$$

в якому $q_{0}>0, \mu>0$ - деякі константи, що визначають потужність осередку.

При $\mu=0$ маємо однорідний осередок, а при $\mu>0$ - неоднорідні осередки, на границі яких $\left(r=r_{0}\right)$ відсутні термоджерела.

Для визначення розподілу надлишкової температури $T(r, t)$ як функції часу $t$ та радіальної координати $r$ будемо розв'язувати диференціальне рівняння

$$
\frac{\partial T}{\partial t}-a\left(\frac{\partial^{2} T}{\partial r^{2}}+\frac{1}{r} \frac{\partial T}{\partial r}\right)=\frac{q(r)}{\rho c} H(t),
$$

де $a=\lambda /(\rho c)$ - коефіцієнт температуропровідності сировини; $\lambda$ - коефіцієнт теплопровідності сировини; $\rho, c$ - відповідно питома маса і питома теплоємність сировини; $H(t)$ - одинична функція Хевісайда; $t$ - час.

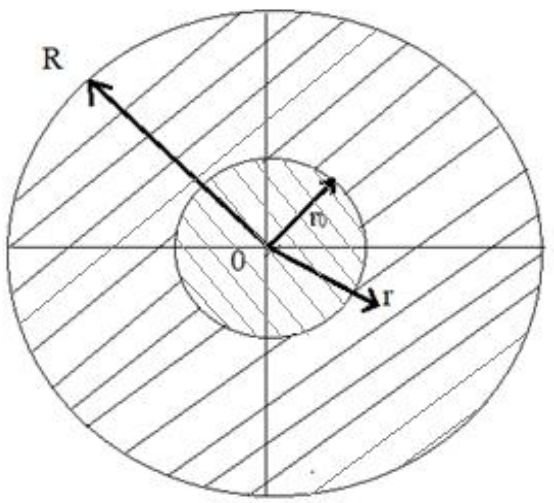

Рис. 1. Розрахункова схема

Fig. 1. Calculation scheme

На боковій поверхні силосу надлишкову температуру задаємо рівною нулю, беручи до уваги низьку теплопровідність сировини. Тому початкову та крайову умови подаємо такими виразами:

$$
\mathrm{T}(r, 0)=0 ; \mathrm{T}(R, t)=0,
$$

що допустимо принаймні на початковому етапі самозігрівання.

Розв'язок рівняння (2) шукаємо у вигляді ряду

$$
\mathrm{T}(r, t)=\sum_{n=1}^{\infty} f_{n}(t) J_{0}\left(s_{n} \frac{r}{R}\right),
$$

де $f_{n}(0)=0 ; s_{n}-$ додатні корені рівняння $J_{0}\left(s_{n}\right)=0 ; J_{0}(Z)-$ функція Бесселя нульового індексу.

Вибір розв'язку у формі (4) задовольняе умови (3).

Враховуючи, що [3; 17]

$\frac{d^{2} J_{0}\left(s_{n} r / R\right)}{d r^{2}}+\frac{1}{r} \frac{d J_{0}\left(s_{n} r / R\right)}{d r}=-\left(\frac{s_{n}}{R}\right)^{2} J_{0}\left(\frac{s_{n}}{R} r\right)$,

після підстановки (4) у (2), маємо рівняння

$$
\frac{d f_{n}}{d t}+a\left(\frac{s_{n}}{R}\right)^{2} f_{n}=\frac{b_{n}}{\rho c}, \quad n=1,2,3, \ldots \ldots
$$


в яких $b_{n}$ коефіцієнти ряду

$$
\sum_{n=1}^{\infty} b_{n} \cdot J_{0}\left(\frac{s_{n}}{R} r\right)=q(r) .
$$

Для визначення $b_{n}$ домножимо обидві частини виразу (6) на $r J_{0}\left(s_{m} r / R\right) d r$ та проінтегруємо від нуля до $R$. Взявши до уваги, що в [7]

$$
\int_{0}^{1} x J_{0}\left(s_{m} x\right) J_{0}\left(s_{n} x\right) d x=\left\{\begin{array}{cc}
\frac{1}{2}\left[J_{1}\left(s_{m}\right)\right]^{2} \\
0
\end{array} \text { при } \begin{array}{c}
m=n \\
m \neq n,
\end{array}\right.
$$

маємо такий вираз:

$$
b_{n}=\frac{2}{R^{2}\left[J_{1}\left(s_{n}\right)\right]^{2}} \int_{0}^{r_{0}} r q(r) J_{0}\left(\frac{s_{n}}{R} r\right) d r .
$$

Тут $J_{1}\left(s_{n}\right)$ - функція Бесселя індексу одиниця.

Далі підставимо вираз (1) в (7) і перейдемо до нової змінної інтегрування: $r=r_{0} u ; d r=r_{0} d u$. Тоді

$$
b_{n}=\frac{2 q_{0} r_{0}^{2}}{R^{2}\left[J_{1}\left(s_{n}\right)\right]^{2}} \int_{0}^{1} u\left(1-u^{2}\right)^{\mu} J_{0}\left(\frac{s_{m} r_{0}}{R} u\right) d u .
$$

Цей інтеграл належить до табличних [7, с. 754]. Тому

$$
b_{n}=\frac{q_{0} r_{0}^{2}}{R^{2}} \frac{2^{\mu+1} \Gamma(\mu+1)}{\left[J_{1}\left(s_{n}\right)\right]^{2}}\left(\frac{R}{s_{m} r_{0}}\right)^{\mu+1} J_{1+\mu}\left(\frac{s_{m} r_{0}}{R}\right)
$$

Тут $\Gamma(Z), J_{1+\mu}(Z)$ - відповідно гаммафункція і функція Бесселя індексу $1+\mu$.

Рівняння (5) мають розв'язки:

$$
f_{n}(t)=\frac{b_{n} R^{2}}{\lambda s_{n}^{2}}\left[1-\exp \left(-a \frac{s_{n}^{2}}{R^{2}} t\right)\right] \text {. }
$$

Підставивши вирази (8) і (9) в (4), маємо розподіл надлишкової температури як в осередку, так і за його межами:

$$
\begin{aligned}
& \mathrm{T}(r, t)=\frac{q_{0} r_{0}^{2}}{\lambda}\left(\frac{2 R}{r_{0}}\right)^{1+\mu} \Gamma(1+\mu) \cdot \\
& \cdot \sum_{n=1}^{\infty} \frac{\left[1-\exp \left(-a \frac{s_{n}^{2} t}{R^{2}}\right)\right] J_{1+\mu}\left(\frac{s_{n}}{R} r_{0}\right) J_{0}\left(s_{n} \frac{r}{R}\right)}{s_{n}^{3+\mu}}
\end{aligned}
$$

Цей ряд дещо спрощується при обчисленні максимальної температури самозігрівання $\mathrm{T}(0, t)$, бо $J_{0}(0)=1$. Тому в центрі осередку маємо:

$$
\begin{aligned}
& \mathrm{T}(0, t)=\frac{q_{0} r_{0}^{2}}{\lambda}\left(\frac{2 R}{r_{0}}\right)^{1+\mu} \Gamma(1+\mu) \cdot \\
& \cdot \sum_{n=1}^{\infty} \frac{\left[1-\exp \left(-a \frac{s_{n}^{2}}{R^{2}} t\right)\right] J_{1+\mu}\left(\frac{s_{n}}{R} r_{0}\right)}{s_{n}^{3+\mu}}
\end{aligned}
$$

Для окремих $\mu$ тут можна прискорити збіжності ряду, якщо перейти до різниці:

$$
\mathrm{T}(0, t)=\mathrm{T}_{\Gamma}(0)-\mathrm{T}_{\partial}(0, t),
$$

де

$$
\begin{aligned}
& \mathrm{T}_{\Gamma}(0)=\frac{q_{0} r_{0}^{2}}{\lambda}\left(\frac{2 R}{r_{0}}\right)^{1+\mu} \Gamma(1+\mu) . \\
& \cdot \sum_{n=1}^{\infty} \frac{J_{1+\mu}\left(\frac{s_{n}}{R} r_{0}\right)}{s_{n}^{3+\mu}\left[J_{1}\left(s_{n}\right)\right]^{2}} \\
& \mathrm{~T}_{\partial}(0, t)=\frac{q_{0} r_{0}^{2}}{\lambda}\left(\frac{2 R}{r_{0}}\right)^{1+\mu} \Gamma(1+\mu) . \\
& \cdot \sum_{n=1}^{\infty} \frac{\exp \left(-a \frac{s_{n}^{2}}{R^{2}} t\right) J_{1+\mu}\left(\frac{s_{n}}{R} r_{0}\right)}{s_{n}^{3+\mu}\left[J_{1}\left(s_{n}\right)\right]^{2}} .
\end{aligned}
$$

Збіжність першого доданка в (11) повільніша, ніж другого. Але для окремих значень $\mu$ суму ряду можна виразити в замкнутій формі. Так, у випадку $\mu=0$ маємо [11]:

$$
\begin{aligned}
& \sum_{n=1}^{\infty} \frac{J_{1}\left(\frac{s_{n}}{R} r_{0}\right)}{s_{n}^{3}\left[J_{1}\left(s_{n}\right)\right]^{2}}=\frac{r_{0}}{4 R}\left(\frac{1}{2}-\ln \frac{r_{0}}{R}\right) ; \\
& \mathrm{T}_{\Gamma}(0)=\frac{q_{0} r_{0}^{2}}{2 \lambda}\left(\frac{1}{2}-\ln \frac{r_{0}}{R}\right) .
\end{aligned}
$$

Якщо $\mu=1$, то

$\sum_{n=1}^{\infty} \frac{J_{2}\left(\frac{s_{n}}{R} r_{0}\right)}{s_{n}^{4}\left[J_{1}\left(s_{n}\right)\right]^{2}}=\frac{2 R}{r_{o}}\left[\sum_{n=1}^{\infty} \frac{J_{1}\left(\frac{s_{n}}{R} r_{0}\right)}{s_{n}^{5}\left[J_{1}\left(s_{n}\right)\right]^{2}}-\frac{J_{0}\left(\frac{s_{n}}{R} r_{0}\right)}{s_{n}^{4}\left[J_{1}\left(s_{n}\right)\right]^{2}}\right]$.

Враховуючи суми в [11], маємо:

$$
\begin{aligned}
& \sum_{n=1}^{\infty} \frac{J_{2}\left(\frac{s_{n}}{R} r_{0}\right)}{s_{n}^{4}\left[J_{1}\left(s_{n}\right)\right]^{2}}=\frac{1}{8}\left(1-\frac{5}{8} \frac{r_{0}^{2}}{R^{2}}+\frac{1}{2} \frac{r_{0}^{2}}{R^{2}} \ln \frac{r_{0}}{R}\right)- \\
& -\frac{1}{8}\left(1-\frac{r_{0}^{2}}{R^{2}}+\frac{r_{0}^{2}}{R^{2}} \ln \frac{r_{0}}{R}\right)=-\frac{1}{16} \cdot \frac{r_{0}^{2}}{R^{2}}\left(\ln \frac{r_{0}}{R}-\frac{3}{4}\right) .
\end{aligned}
$$


Тоді $\mathrm{T}_{\Gamma}(0)=\frac{1}{4} \frac{q_{0} r_{0}^{2}}{\lambda}\left(\frac{3}{4}-\ln \frac{r_{0}}{R}\right)$.

Аналогічно можна отримати замкнені вирази $\mathrm{T}_{\Gamma}(0)$ і для інших цілих $\mu$, але на цьому питанні зупинятися не будемо.

Цінність замкнених виразів для $\mathrm{T}_{\Gamma}(0)$ полягає не тільки в тому, що їх використання прискорює збіжність ряду для $\mathrm{T}(0, t)$, а ще й у тому, що це граничні значення температури, які виникають при самозігріванні. Більшою, ніж $\mathrm{T}_{\Gamma}(0)$, подана виразом (13), не може бути надлишкова температура в цій моделі за будь-яких $t$ i $\mu$.

Якщо обмежитись визначенням тільки приростів температури

$$
\Delta \mathrm{T}(0, t)=\mathrm{T}(0, t)-\mathrm{T}\left(0, t_{1}\right),
$$

то $\mathrm{T}_{c}(0, t)$ не потрібні, бо

$$
\Delta \mathrm{T}(0, t)=\mathrm{T}_{\partial}(0, t)-\mathrm{T}_{\partial}\left(0, t_{1}\right),
$$

де $t_{1}$ - час, коли відбулося перше вимірювання температури $\mathrm{T}\left(0, t_{1}\right)$.

За використання формули (14) доводиться наближено обчислювати суми рядів більш швидкої збіжності (12). Для цього потрібні значення додатних коренів $s_{n}$. Згідно 3 [3] два перші з них мають значення $\quad S_{1} \approx 2,40482555$; $s_{2}=5,52007811$, а решта визначається асимптотичною формулою Макмагона [7]:

$$
\begin{aligned}
& s_{n} \approx \frac{\pi}{4}(4 n-1)+\frac{1}{2 \pi(4 n-1)}- \\
& -\frac{31}{6 \pi^{3}(4 n-1)^{3}}+\frac{3779}{15 \pi^{5}(4 n-1)^{5}}, \quad n \geq 2 .
\end{aligned}
$$

Уже при $n=2$ формула дає $s_{2} \approx 5,5200867$, що незначно відрізняється від вказаного вище більш точного значення.

Значення функцій Бесселя можна обчислювати за допомогою степеневих рядів [3; 17]. Але для функцій цілого індексу зручніше використовувати наближення [3]:

$$
\begin{gathered}
J_{0}(x) \approx 1-2,2499997 y^{2}+1,2656208 y^{4}- \\
-0,3163866 y^{6}+0,0444479 y^{8}- \\
-0,0039444 y^{10}+0,0002100 y^{12} ; \\
J_{1}(x) \approx x \times\left(0,5-0,56249985 y^{2}+0,21093573 y^{4}-\right. \\
-0,3954289 y^{6}+0,00443319 y^{8}-0,00031761 y^{10}+
\end{gathered}
$$

$\left.\left.+0,00001109 y^{12}\right)-0,00031761 y^{10}+0,00001109 y^{12}\right)$,

в яких $y=x / 3 ; x \leq 3$.

Для великих аргументів, коли $x>3$ [3],

маємо:

$$
\begin{aligned}
& J_{0}^{|x|} \approx \frac{1}{\sqrt{x}} f_{0} \cos \theta_{0} ; J_{1}(x) \approx \frac{1}{\sqrt{x}} f_{1} \cos \theta_{1} . \\
& f_{0}=0,79788456-0,00000077 Z- \\
& 0,00552740 Z^{2}-0,00009512 Z^{3}+ \\
& +0,00137237 Z^{4}-0,00072805 Z^{5}+ \\
& +0,00014476 Z^{6} ; \\
& f_{1}=0,79788456+0,00000156 Z+ \\
& +0,01659667 Z^{2}+0,00017105 Z^{3}- \\
& +0,00249511 Z^{4}+0,00113653 Z^{5}- \\
& -0,00020033 Z^{6}, \\
& \theta_{0}=x-0,78539816-0,04166397 Z- \\
& -0,00003954 Z^{2}+0,00262573 Z^{3}- \\
& -0,00054125 Z^{4}-0,00029333 Z^{5}+ \\
& +0,00013558 Z^{6}, \\
& \theta_{1}=x-2,35619449+0,12499612 Z+ \\
& +0,00005650 Z^{2}-0,00637879 Z^{3}+ \\
& +0,00074348 Z^{4}+0,00079824 Z^{5}- \\
& -0,00029166 Z^{6} \\
& Z=3 / x
\end{aligned}
$$

Похибка асимптотичних наближень менша $10^{-7}$.

Знаючи $J_{0}(x)$ i $J_{1}(x)$, функції Бесселя цілого індексу, більшого одиниці, легко визначити за рекурентним співвідношенням

$$
J_{n+1}(x)=\frac{2 n}{x} J_{n}(x)-J_{n-1}(x), \quad n=1,2,
$$

Чисельна реалізація розв'язку, крім теплофізичних характеристик сировини, потребує значень параметрів осередку: $q_{0}, r_{0}, \mu$, які здебільшого невідомі. Для їх визначення існують різні способи ідентифікації $[9 ; 11 ; 12]$ з використанням експериментально визначених значень температури в окремі моменти часу. Після проведення ідентифікації викладена теоретична модель придатна для прогнозу зміни температури самозігрівання з плином часу.

Числові результати. Для проведення розрахунків задаємо: 


$$
\begin{aligned}
& R=5 м ; r_{0}=0,1 R ; \lambda=0,09 \mathrm{Bm} /\left({ }^{\prime} K\right) ; \\
& \rho c=8,5 \cdot 10^{5} \text { Дж } /\left(\mathcal{M}^{3} K\right)
\end{aligned}
$$

Такі теплофізичні характеристики має трав'яне борошно [5]. Збіжність ряду в (10) найповільніша при $\mu=0$. Розглянемо ії детальніше. Результати обчислень безрозмірного параметра $\mathrm{T}_{*}(0, t)=\frac{\lambda}{q_{0} r_{0}^{2}} \mathrm{~T}(0, t)$ з різним числом членів $n_{*}$ в (10) при різних $t$ записано в чисельниках у табл. 1.
У знаменники записано значення безрозмірного параметра, одержані за формулами (11) (13). У другому варіанті розрахунку збіжність розв'язку значно швидша, ніж у першому. Збіжність рядів прискорюється зі зростанням часу $t$, хоча практична реалізація розв'язку неможлива без використання комп'ютера.

Значення безрозмірного параметра $\mathrm{T}_{*}(0, t)$ за інших варіантів розподілу термоджерел в осередку (1) записано в табл. 2.

Таблиця 1. Значення $10 \cdot \mathrm{T}_{*}(0, t)$ при різних $t(\mu=0)$

Table 1. Values of $10 \cdot \mathrm{T}_{*}(0, t)$ for $t(\mu=0)$

\begin{tabular}{|c|c|c|c|c|}
\hline \multirow{2}{*}{$t$, діб } & $n_{*}=5$ & $n_{*}=10$ & $n_{*}=50$ & $n_{*}=100$ \\
\cline { 2 - 5 } & \multicolumn{3}{|c|}{ Значення $10 \cdot \mathrm{T}_{*}(0, t)$} \\
\hline \multirow{2}{*}{10} & $\frac{1,647}{3,068}$ & $\frac{2,915}{2,777}$ & $\frac{2,782}{2,776}$ & $\frac{2,775}{2,776}$ \\
\hline \multirow{2}{*}{20} & $\frac{2,846}{4,217}$ & $\frac{4,284}{4,146}$ & $\frac{4,152}{4,146}$ & $\frac{4,145}{4,146}$ \\
\hline \multirow{2}{*}{50} & $\frac{4,831}{6,202}$ & $\frac{6,338}{6,200}$ & $\frac{6,205}{6,200}$ & $\frac{6,199}{6,200}$ \\
\hline 100 & $\frac{6,480}{7,850}$ & $\frac{7,988}{7,850}$ & $\frac{7,856}{7,850}$ & $\frac{7,849}{7,850}$ \\
\hline
\end{tabular}

Таблиця 2. Значення $10 \cdot \mathrm{T}_{*}(0, t)$ при $\mu=0,5$ і $\mu=1$

Table 2. Values of $10 \cdot \mathrm{T}_{*}(0, t)$ for $\mu=0,5$ and $\mu=1$

\begin{tabular}{|c|c|c|c|c|c|}
\hline \multirow{2}{*}{$t$, діб } & $\mu=0,5$ & $\mu=1$ & \multirow{2}{*}{$t$, діб } & $\mu=0,5$ & $\mu=1$ \\
\cline { 2 - 3 } \cline { 5 - 6 } & \multicolumn{2}{|c|}{$10 \cdot \mathrm{T}_{*}(0, t)$} & & \multicolumn{2}{|c|}{$10 \cdot \mathrm{T}_{*}(0, t)$} \\
\hline 10 & 2,222 & 1,892 & 100 & 5,690 & 4,536 \\
\hline 20 & 3,179 & 2,633 & 200 & 6,822 & 5,389 \\
\hline 50 & 4,579 & 3,697 & - & - & - \\
\hline
\end{tabular}

Як бачимо, при збільшенні показника $\mu$ сповільнюється зростання температури в осередку, бо маємо меншу сумарну потужність термоджерел у ньому.

Для обчислення значень надлишкової температури, а також прогнозування іiі розвитку, потрібні значення $q_{0}, \mu, r_{0}$. Їх можна наближено ідентифікувати за результатами вимірювання температури на початковому етапі самозігрівання. Для цього за формулою (10) побудовано графіки відношення температури:

$$
\eta=\mathrm{T}\left(0, t_{2}\right) / \mathrm{T}\left(0, t_{1}\right),
$$

при різних відношеннях $r_{0} / R$ і трьох значеннях $\mu$ (рис. 2-4). Графік 1 (див. рис. 2) встановлено при $t_{1}=5$ діб, $t_{2}=10$ діб, а графік $2-$ при $t_{1}=5$ діб, $t_{2}=15$ діб. $\mathrm{y}$ другому випадку сепарабельна спроможність графіка краща, ніж у першому, але при цьому збільшується час на проведення ідентифікації, що небажано на практиці (див. рис. 2). Графіки дають змогу знайти розмір осередку $\left(r_{0} / R\right)$ за експериментально визначеним $\eta$. Можливості графіків обмежені через те, що при збільшенні $r_{0}$ втрачає інформаційну властивість точка вимірювання температури $r=0$, бо збільшення радіуса осередку призводить до того, що зростання температури в його центрі відбувається за лінійним законом, як у необмеженому тілі з рівномірним розподілом термоджерел. Тоді розмір осередку не $\epsilon$ значущим. Отже, для ідентифікації параметрів осередку великого радіуса потрібно вимірювати температури не в центрі осередку. Після визна- 
чення $r_{0}$ нескладно знайти й параметр щільності термоджерел $q_{0}$, бо згідно з (10)

$$
\begin{aligned}
& q_{0}=\mathrm{T}\left(0, t_{2}\right)\left\{\frac{r_{0}^{2}}{\lambda}\left(\frac{2 R}{r_{0}}\right)^{1+\mu} \Gamma(1+\mu) .\right. \\
& \left.\quad \cdot \sum_{n=1}^{\infty} \frac{\left[1-\exp \left(-a \frac{s_{n}^{2}}{R} t_{2}\right)\right] J_{1+\mu}\left(\frac{s_{n}}{R} r_{0}\right)}{s_{n}^{3+\mu}\left[J_{1}\left(s_{n}\right)\right]^{2}}\right\}
\end{aligned}
$$

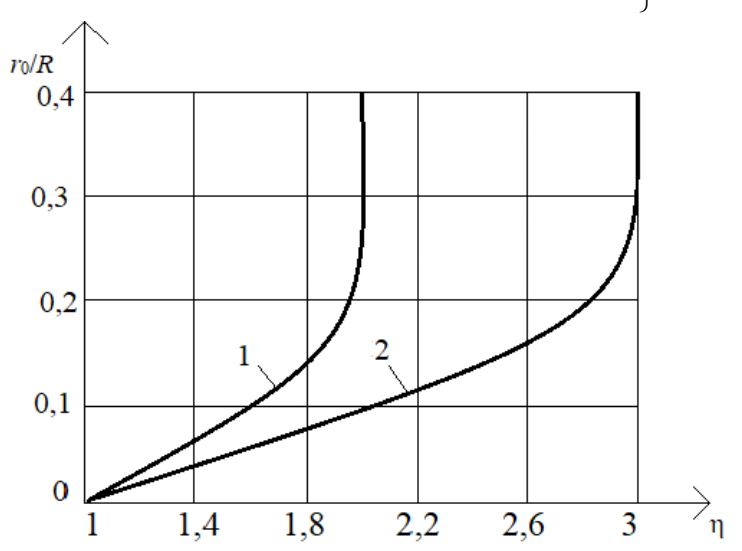

Pис. 2. Графіки $r_{0} / R$ при $\mu=0$ :

$1-t_{2}=2 t_{1}=10$ діб; $2-t_{2}=3 t_{1}=15$ діб

Fig. 2. Graphs $r_{0} / R$ at $\mu=0: 1-t_{2}=2 t_{1}=10$ days;

$$
2-t_{2}=3 t_{1}=15 \text { days }
$$

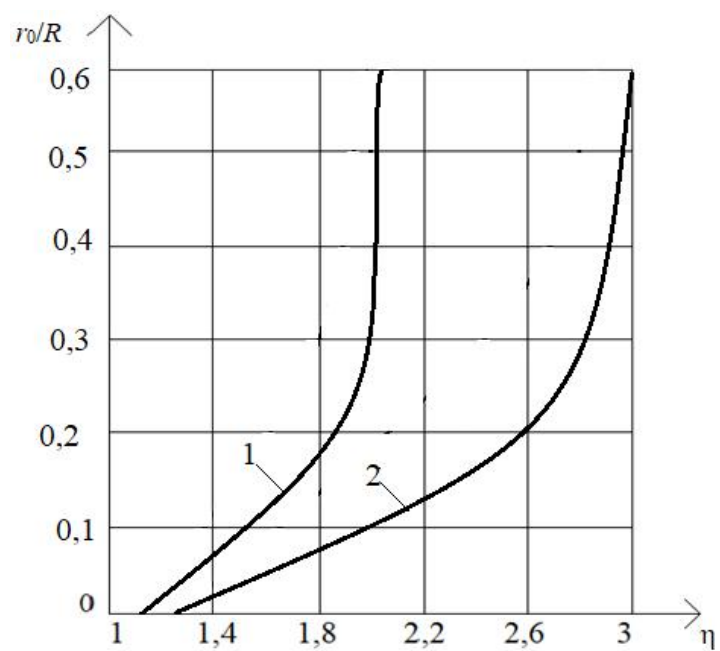

Рис. 3. Графіки $r_{0} / R$ при $\mu=0,5$ :

$1-t_{2}=2 t_{1}=10$ діб; $2-t_{2}=3 t_{1}=15$ діб

Fig. 3. Graphs $r_{0} / R$ at $\mu=0,5: 1-t_{2}=2 t_{1}=10$ days;

$$
2-t_{2}=3 t_{1}=15 \text { days }
$$

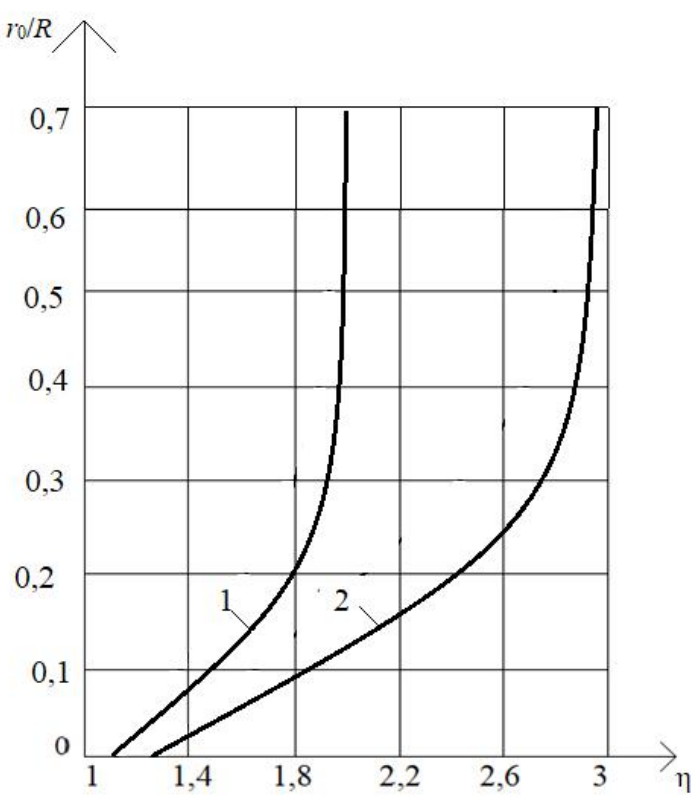

Рис. 4. Графіки $r_{0} / R$ при $\mu=1$ :

$1-t_{2}=2 t_{1}=10$ діб; $2-t_{2}=3 t_{1}=15$ діб

Fig. 4. Graphs $r_{0} / R$ at $\mu=1: 1-t_{2}=2 t_{1}=10$ days;

$$
2-t_{2}=3 t_{1}=15 \text { days }
$$

Приклад 1. Нехай за результатами вимірювання $\mathrm{T}\left(0, t_{1}\right)=8^{\circ} C$, а $\mathrm{T}\left(0, t_{2}\right)=12^{\circ}$ при $t_{1}=5$ діб, $t_{2}=10$ діб. Тоді $\eta=1,5$. При $\mu=0$ на графіку 1 (див. рис. 2) маємо $r_{0} / R=0,072 \Rightarrow r_{0}=0,36 \quad$ м. Підстановка відповідних чисел до формули (15) дає $q_{0}=20,48 \frac{B m}{M^{3}}$.

Приклад 2. При $\mu=1, t_{1}=5$ діб, $t_{2}=15$ діб було встановлено, що $\mathrm{T}\left(0, t_{1}\right)=5^{\circ} \mathrm{C}$, а $\mathrm{T}\left(0, t_{2}\right)=13^{\circ}$. На графіку 2 (див. рис. 4) при $\eta=2,6$ маємо: $r_{0} / R=0,24 ; r_{0}=1,2$ м. Для цих параметрів i вказаних вище теплофізичних характеристик трав'яного борошна за формулою (15) одержуємо $q_{0} \approx 10,5 \frac{\mathrm{Bm}}{\mathrm{M}^{3}}$.

Після ідентифікації $r_{0}$ i $q_{0}$ можна проводити розрахунковий прогноз зростання температури в осередку самозігрівання за формулою (10).

Висновки. Одержаний аналітичний розв'язок нестаціонарної задачі теплопровідності в поєднанні 3 експериментальним вимірюванням 
температури в центрі осередку самозігрівання дає змогу визначити параметри внутрішнього локалізованого термоджерела й провести прогноз розвитку температури самозігрівання. Реалізація цього способу дослідження процесу самозігрівання сировини в силосі можлива лише 3 використанням комп'ютерних способів розрахунку.

\section{Бібліографічний список}

1. Абрамов Ю. А., Кирочкин А. Ю. Математические модели тепловых полей насыпи растительного сырья с учётом температуры окружающей среды. Пожаровзрывобезопасность. 2000. № 3. С. 21-27.

2. Абрамов Ю. А., Кирочкин А. Ю., Откидач Д. Н. Математическая модель теплового поля зерновой насыпи. Пожаровзрывобезопасность. 1999. № 2. C. 25-29.

3. Абрамовиц М., Стиган И. Справочник по специальным функциям (с формулами, графиками и математическими таблицами). Москва: Наука, 1979. 832 с.

4. Альбощий В. М. Разработка методов и средств пожарной безопасности хранилищ растительного сырья: дисс. ... канд. техн. наук. Харьков, 2000. $181 \mathrm{c}$.

5. Вогман Л. П., Горшков В. И., Дегтярев А. Г. Пожарная безопасность элеваторов. Москва: Стройиздат, 1993. $288 \mathrm{c}$.

6. Горшков В. И., Корольченко И. А., Казаков А. В., Соколов Д. Н. Определение времени индукции при очаговом самовозгорании материалов. Пожарная безопасность. 2007. № 1. С. 66-70.

7. Градштейн И. С., Рыжик И. М. Таблицы интегралов сумм, рядов и произведений. Москва: Физматгиз, $1962.1100 \mathrm{c}$.

8. Дегтярев А. Г., Вогман Л. П. Оптический способ обнаружения самовозгорания и горения в хранилищах сельскохозяйственного сырья. Пожаровзрывобезопасность. 1999. № 6. С. 37-41.
9. Ерёменко С. А., Ольшанский В. П. Задачи нестационарной теплопроводности при самонагревании сырья пластовыми очагами. Харьков: ХНАДУ, 2003. 164 с.

10. Кирочкин А. Ю., Абрамов Ю. А. Распределение температуры в гнездовом органическом веществе. Проблемы пожарной безопасности. 2000. Вып. 7. С. 106-111.

11. Криса И. А., Ольшанский В. П. Стационарные температурные поля при самонагревании растительного сырья (их расчет и реконструкция). Киев: Пожінформтехніка, 2003. 296 с.

12. Ларин А. Н., Ольшанский В. П., Тригуб В. В. Задачи нестационарной теплопроводности при самонагревании сырья гнездовыми очагами. Харьков: ХНАДУ, 2003. 160 с.

13. Ольшанский В. П., Тригуб В. В. К расчету температуры самонагревания растительного сырья гнездовым сферическим очагом. Вестник ХГПУ. Новые решения в современных технологиях. 2000. Вып. 118. С. 43-45.

14. Орликова В. П., Волынец В. В. Изучение очагового самовозгорания органических веществ. Пожарная безопасность: проблемы, пути совершенствования. 2019. № 2(3). С. 169-177.

15. Соколов Д. Н. Оценка возможности самовозгорания зерна в силосах элеватора. Инновационные технологии производства и хранения материальных ценностей для государственных нужд. 2017. № 7. С. 284-287.

16. Сухарева А. Р., Шуханов С. Н. Состояние вопроса самонагревания хлебной массы в скирдах. Известия Оренбургского государственного аграрного университета. 2018. № 3(71). С. 165-166.

17. Янке Е., Эмде Ф., Леш Ф. Специальные функции. Москва: Наука, 1977. 344 с.

18. Olshanskii V. P. Temperature field of bedded self-heating of a bankin a silo. Combustion, Explossion, and Shock Waves. 2001. Vol. 37, issue 1. P. 53-56.

19. Olshanskii V. P. Temperature field of clusterself-heating of a bankin a silo. Combustion, Explossion, and Shock Waves. 2002. Vol. 38, issue 6. P. 728-732.

Стаття надійшла 24.06.2021 